everything will be ready to begin regular observing with the magnificent equipment next spring, by which time the preliminary experimental work of adjusting will be completed.

The rapid progress on the telescope is largely due to the excellent plans which were prepared by Dr. J. S. Plaskett in consultation with the Brashear and the Warner and Swasey companies. Dr. Plaskett will have charge of the instrument when completed.

\section{SIR FREDERICK DONALDSON, K.C.B.}

A $\mathrm{S}$ announced in last week's Narure (p. 307), A Sir Hay Frederick Donaldson, an engineer of distinction, perished in the disaster to H.M.S. Hampshire, on June 5 , when accompanying Lord Kitchener as a representative of the Ministry of Munitions with the special rank of BrigGeneral. He held successively the positions of deputy-director-general, chief mechanical engineer, and chief superintendent of the Royal Ordnance Factories, Woolwich. He was assocated with, and largely responsible for, the great improvements in the power and mechanism of naval and land artillery during the last twenty years. Since the beginning of the war his energies were severely taxed in assisting to meet the demand for an enormously increased supply of munitions of every description, and in augmenting the productive capacity of the Royal Arsenal. Some months ago he was appointed chief technical adviser to the Ministry of Munitions.

Born in $185^{6}$, at Sydney, Sir Frederick was the second son of Sir Stuart A. Donaldson, the first Premier of New South Wales. He was educated at Eton, Trinity College (Cambridge), Edinburgh, and Zurich He was a pupil of the late Mr. Webb at the L. and N.W. Railway works at Crewe. Afterwards he was executive engineer on the West of India Portuguese Railway and Harbour, engineer-in-charge of No. I Section of the Manchester Ship Canal, and engineer-in-chief to the London and India Docks Joint Committee. Then in 1897 he went to Woolwich, where his chief work was accomplished.

In addition to his professional avocations, Sir Frederick took a great interest in the scientific side of engineering. He was a member of the Council of the Institutions of Civil Engineers, Mechanical Engineers, and of the Iron and Steel Institute. In 1913 and 1914 he was president of the Institution of Mechanical Engineers, took an energetic part in guiding its affairs, and delivered an admirable address dealing with the education and the workshop training of engineers. He was actively interested in the work of the Engineering Standards Committee, and was chairman of the committee on screw threads and limit gauges. The investigations of this committee have certainly led to increased accuracy of workmanship and to extensions of the mudern system of manufacturing machines with parts interchangeable without needing adjustment. At its instance a lathe of the highest accuracy was installed at the National Physical Laboratory, which can be used NO. 2433, VOL. 97] in correcting lathe leading screws. In $1909 \mathrm{Sir}$ Frederick gave an instructive lecture at the Institution of Mechanical Engineers on "The Interchangeability of Screw Threads." He also proposed a scheme for the registration of the results of scientific researches carried out in private laboratories and those attached to factories and manufacturing works, with the object of preventing reduplication of effort. Valuable as such a system would be, it has not so far been found practicable.

To great ability and wide engineering knowledge Sir Frederick added unfailing tact and great courtesy and charm of manner, and enjoyed the esteem of all who were associated with him. His colleagues mourn his loss, which to them and to the country is irreparable.

\section{MR. LESLIE S. ROBERTSON.}

$A$ PPOINTED to the staff as a representative $A$ of the Ministry of Munitions, and with the special rank of Lieut.-Col., Mr. Leslie Robertson met his death on the ill-fated mission of Lord Kitchener to Russia. He was born in India in 1863 , the youngest son of Sir W. R. Robinson, K.C.S.I., Governor of Madras, who resumed an earlier family name in 1898 . He was educated in Germany and at King's and University Colleges in London. He was technically trained in the works of Messrs. Denny and Co., Dumbarton, and Messrs. J. I. Thornycroft, Chiswick. Then he was in private practice for a time, during which he represented in this country the important firm of Normand, of Havre.

In rgor he became secretary to the Engineering Standards Committee, the work of which he carried on for fourteen years with an enthusiasm and ability to which much of its success is due. Founded initially to standardise rolled sections of steel, the work of this committee has extended to nearly all the materials largely used in engineering, and to a variety of manufactured products from locomotives to glow-lamps. Further, it has standardised tests and specifications. An army of engineers, users, and manufacturers, including representatives of the War Office and Admiralty, formed its sectional committees, giving their services gratuitously, and greatly helped by the tactful arrangements made by Mr. Robertson to economise their time. The results are becoming of increasing importance from an international point of view. In I9I2 Mr. Robertson was secretary to delegates sent by the Board of Trade to a congress in New York of the important International Association for Testing Materials, founded by Bauschinger in 1884 .

In August, I9I 5, Mr. Robertson was appointed assistant director of production in the Ministry of Munitions, and was concerned with organising the production of the metal components of ammunition. One of his colleagues at Armament Buildings writes that "his almost unique knowledge of the capacity of the workshops of Great Britain and of the men in charge of them was invaluable in negotiations, leading to the enormous 